\title{
Diversity of avifauna at the Bangladesh Academy for Rural Development (BARD), Kotbari, Comilla
}

\author{
M. Firoj Jamam ${ }^{1^{*}}$, Md. Saidur Rahman ${ }^{2}$, Muhammad Enamul Haque ${ }^{2}$ \\ ${ }^{1}$ Department of Zoology, University of Dhaka, Dhaka 1000, email: mfjaman@yahoo.com \\ ${ }^{2}$ Department of Zoology, University of Jagannat, Dhaka
}

\begin{abstract}
The diversity of avifauna at the BARD (Bangladesh Academy for Rural Development), Comilla was studied from March, 2010 to March, 2011. A total of 41 species of birds (20 non-passerines and 21passerines) were identified. Among the total species, $37(90.25 \%)$ were resident and $4(9.75 \%)$ were winter migrants. Regarding to the habitat types utilized by individual species, 11 was bush dwellers, 5 at open place, 5 on human habitations, 4 on tall trees, 10 in garden, 6 found at near the pond. Relative abundance (by number) showed that 10 species were very common, 25 common, 9 fairly common and 7 few. The highest density was recorded for Passer domesticus (480.15 indiv. / acre) and the lowest was for Dicrurus macrocercus (1.29 indiv. / acre). Among these birds, $18(43.91 \%)$ species were insectivores, $6(14.64 \%)$ piscivores, $6(14.64 \%)$ granivores, $2(4.88 \%)$ frugivores, $4(9.76 \%)$ rodentivores, only one $(2.44 \%)$ nectar feeder and the rest $3(7.32 \%)$ were mixed feeders. Among the avifauna, $8(21.63 \%)$ species were included in the threatened category, of which $2(5.41 \%)$ were critically endangered, $3(8.11 \%)$ endangered and $3(8.11 \%)$ vulnerable nationally. Direct communication with local people recorded that illegal exploitation of forest, trapping, shooting of birds and collection of young as cage birds are the mentionable causes of decline of the diversity and population of avifauna in the study area. Control of unwise exploitation, plantation of indigenous fruit-trees and creation of awareness, preparation of integrated management action plan (IMAP) and its implementation in co-operation with National and International organizations are mostly essential for conservation of avian diversity in the study area.
\end{abstract}

Keyword: Ecology, diversity, avifauna, BARD, conservation.

\section{Introduction}

Among the total 1200 species of birds recorded in Indian subcontinent (Ali \& Ripley, 1983), Bangladesh represented 628 species, of which 41 were threatened (Annonymus, 2000). Although, a total of 718 bird species under 64 families was reported by Khan (2010). Bird is an important wild animal as they helps in pest control, pollination, cleaning the environment as scavenger as well as an important ecological indicator (Ali \& Ripley, 1983). Study site has been representing many species of birds that need to be documented for their protection.

Some studies on the diversity of avifauna were performed elsewhere (Rahman, 1971; Husain \& Sarker, 1979; Husain et al., 1983; Sarker, 1983; Hossain \& Sarker, 1997). Haque (1975) and Jaman et al. (2004) surveyed and discussed about ecology and conservation of avifauna. So far known no any extensive and methodical collection of data on avifauna at the Bangladesh Academy for Rural Development (BARD), Comilla and associated areas was done in the past. Due to the lack of baseline data it is difficult to know exactly how many species of birds are present in this area; and without baseline data it is very difficult to prepare any conservation plan for the protection of avifauna. Therefore, current study was conducted on avifauna at BARD to reveal the status, distribution, food habits and habitats of individual species of bird. We also attempted to study the vegetation at BARD. Due to the uniform physical features and vegetation as well as importance of study site to the tourist, we considered BARD, Comilla is a suitable place for the study of avian diversity.

\section{Materials and Methods}

This study was based on direct field observation started from March 2010 to April 2011. Data collection was done once in a month for 6 to 7 days and continued from early morning to evening during the whole study period. For data collection transects line and plotting methods were employed. Information was also collected through the direct communication with local people.

Transect line: in this method birds were observed and counted on each side of the transect line (size: $1000 \mathrm{~m}$ long $\times 100 \mathrm{~m}$ width) and recorded. A total of 50 transect lines were made across the study site.

Plot counting: four plots (size: $500 \mathrm{~m} \times 100 \mathrm{~m}$ ) were also selected to study the birds. A total of 50 plots were made to count individual species of birds within the study site. During observation, movement of observer was kept at a uniform speed and while walking along a route, attempts were made to note the birds when they were whiting, singing or flying over the study area or foraging and feeding. Sometimes portable hide were used for closer observation. Two pairs of binoculars (Prism a $20 \times 50$ ), digital camera (Canon Kiss Model 2009), video camera (Sony, Model 2008), GPS, distance measuring plastic tape and chemicals were used during data collection. Field guides on birds (Ali \& Ripley, 1968-1974; Ali \& Ripley, 1983; Khan, 2010) were used in order to identify species during observation. During the analysis of data in the laboratory after taking the pictures or videos from the field, the collected data were compared with the mentioned books. 
Museum specimens of birds of the Department of Zoology, University of Dhaka were also used to identify collected specimens and pictures of birds taken from the study site. All collected data were imputed in the computer to make the systematic data base for each species and categorized according to the taxonomic position. Habitat types, food habits, etc were also recorded.

Study Area: Bangladesh represents a unique zoogeographical zone having all possible types of habitats comprising the fauna and flora. The present study was carried out in Bangladesh Academy for Rural Development (BARD) of Comilla district in Bangladesh, where there are many species of birds occurred. It is situated between $23^{\prime} 26^{\circ}$ north latitudes and $91^{\prime} 7^{0}$ longitudes East. BARD is located at Kotbari, a rural area along the Mainamati-Lalmati (one of the archeological sites of Bangladesh) hill range in Comilla district at a distance of about 10 kilometers from Comilla Sadar town. The sprawling campus covers an area of about 156 acres of land including undulating hilly terrain and valleys. The Academy was established in 1959 basically as a training institute to train government officials and village organization in various subjects' relation to rural development. Important vegetations are: 77 species of tall trees (e.g., Acacia catechu, A. moniliformis, A. nilotica, Aegle marmelos, Albizia spp., Alstonia scholaris, Anthocephalus chinensis, Artocarpus heterophyllus, Azardirachta indica, Bombax ceiba, Butea saperba, Cassia fistula, Cocos nucifera, Dalbargia sisso, Delonix regia, Eucalyptus citriodora, Ficus bengalensis, F. comosa, Mangifera indica, Syzygium cumini, Tamarindus indica, Zizyphus maritiana) and agricultural plants (e.g., Brassica spp., Lathurus sativus, Oryza sativa, Triticum aestivum, etc.).

Temperature: November to June is the hot season but have some wet days. June to October is rainy season. The highest temperature is $36.7^{\circ} \mathrm{C}$ in October and the lowest is $8.6^{\circ} \mathrm{C}$ in February

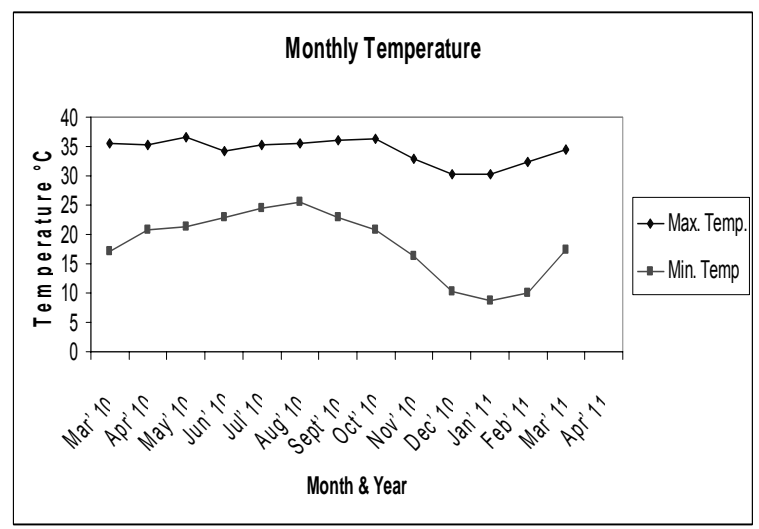

Fig. 1. Average monthly temperature in the study site.

\section{Results and Discussion}

A total of 41 species of birds were identified at BARD (Table 1). Of these, 37 species were resident and 4 winter migrants. Harvey (1990) found 42 species of birds in the same habitat those were belonged to 10 orders and 21 families. Of those, 38 species were resident and 4 winter migrants. In Rangpur, Islam (1970) recorded 82 species of birds and in Faridpur, Rahman (1971) recorded 109 species. Das (1992) reported 110 species from Sylhet and Akter (1997) found 47 species of birds in an urban habitat, the Baldah Garden, Dhaka.

Regarding to the relative abundance of individual species, $11(26.83 \%)$ species were very common, 18 (43.9\%) common, 8 (19.51\%) fairly common and 4 $(9.76 \%)$ species few in number (Table 1 and Fig. 2 ).

The highest density was recorded for house sparrow (Passer domesticus, 480.15 indiv./ acre) followed by pied starling (Sturnus contra, 285.9 indiv./ acre), common myna (Acridotheres tristis, 210.9 indiv./ acre) and jungle myna (A. fuscus, 114.8 indiv./ acre) (Table 1).

Regarding to the feeding habits, the highest number of birds $(18,46.34 \%)$ were insectivorous followed by piscivores (14.63\%) and mixed feeders $(12.19 \%)$ (Table 1 \& Fig. 3). Husain et al. (1992) reported 45 species of insectivorous birds, eight raptorial, 13 piscivorous, three nectar feeders, 11 granivorous, two seed eaters, 10 frugivorous and 18 omivorous along the roadside birds between Chittagong and Tecknaf. We found that each species of bird utilize diverse habitats during feeding, roosting and nesting time in the study site. Majority of the avifauna recorded on the tall trees $(53.65 \%)$ followed by bushes $(39.02 \%)$ and open fields (36.58\%) (Table 1).

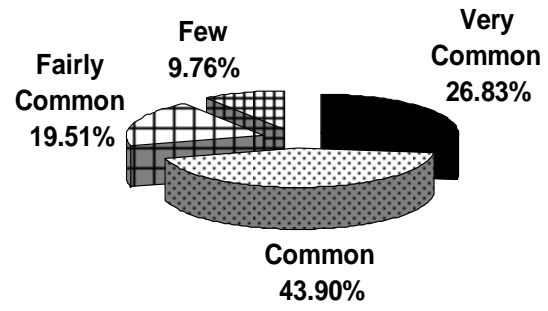

Fig.2. Relative abundance of birds in the study area. 
Table 1. List of avifauna with their status at the BARD

\begin{tabular}{|c|c|c|c|c|c|c|c|c|c|}
\hline \multirow{2}{*}{$\begin{array}{l}\text { Non-passerine birds } \\
\text { Class - Aves }\end{array}$} & \multirow[t]{2}{*}{ Scientific Name } & \multirow[t]{2}{*}{ English Name } & \multirow[t]{2}{*}{ Local Name } & \multirow[t]{2}{*}{${ }^{1} \mathbf{P D}$} & \multicolumn{2}{|c|}{${ }^{2}$ RA/RS } & \multirow[t]{2}{*}{$\begin{array}{c}{ }^{3} \text { IUCN } \\
\text { NS } \\
\end{array}$} & \multirow[t]{2}{*}{${ }^{4} \mathbf{H U}$} & \multirow[t]{2}{*}{${ }^{5} \mathrm{FH}$} \\
\hline & & & & & & & & & \\
\hline \multicolumn{10}{|l|}{ Order - Pelecaniformes } \\
\hline \multirow{3}{*}{$\begin{array}{l}\text { Family- Phalacrocoracida } \\
\text { Order -Ciconiformes } \\
\text { Family -Ardeidae }\end{array}$} & Phalacrocorax niger & Little Cormorant & Choto pankawri & 10.90 & $\mathrm{~F}$ & $\mathrm{R}$ & VU & $\mathrm{R}$ & $\mathrm{P}$ \\
\hline & Ardeola grayii & Pond Heron & Kanibok & 23.08 & FC & $\mathrm{R}$ & LR & Of, CL, P,C & $\mathrm{P}$ \\
\hline & Egretta intermedia & Intermediate Egret & Maijjabok & 20.52 & FC & $\mathrm{R}$ & VU & We, R, P & $\mathrm{P}$ \\
\hline \multicolumn{10}{|l|}{ Order - Falconiformes } \\
\hline \multirow[t]{2}{*}{ Family - Accipitridae } & Milvus migrans & Pariah Kite & Bhuban cheel & 45.52 & $\mathrm{C}$ & $\mathrm{R}$ & CR & Of, $\mathrm{Tt}$ & $\mathrm{R}$ \\
\hline & Haliastur indus & Brahminy Kite & Sankhacheel & 25.65 & $\mathrm{C}$ & $\mathrm{R}$ & DD & Of, $\mathrm{Cl}, \mathrm{Tt}$ & $\mathrm{R}$ \\
\hline \multicolumn{10}{|l|}{ Order - Columbiformes } \\
\hline \multirow[t]{4}{*}{ Family - Columbidae } & Treron phoenicopterus & Green Pigeons & Harial & 25.00 & $\mathrm{C}$ & $\mathrm{R}$ & EN & $\mathrm{Bh}, \mathrm{Tt}$ & $\mathrm{F}$ \\
\hline & Columba livia & Rock Pigeon & Jalali kabuatar & 33.34 & $\mathrm{C}$ & $\mathrm{R}$ & LR & Hh, Of, Cl & G \\
\hline & Streptopelia. chinensis & Spotted Dove & Tilaghugu & 87.18 & $\mathrm{C}$ & $\mathrm{R}$ & EN & Of, Tt & M \\
\hline & S. decaocto & Ring Dove & Raj ghugu & 32.06 & $\mathrm{C}$ & $\mathrm{R}$ & CR & $\mathrm{Bh}, \mathrm{Tt}$ & M \\
\hline \multicolumn{10}{|l|}{ Order - Psittaciformes } \\
\hline \multicolumn{10}{|l|}{ Order - Cuculiformes } \\
\hline \multicolumn{10}{|l|}{$\begin{array}{l}\text { Family - Cuculidae } \\
\text { Order - Strigiformes }\end{array}$} \\
\hline \multicolumn{9}{|l|}{ Order - Coraciformes } & $\mathrm{R}$ \\
\hline \multirow[t]{3}{*}{ Family - Alcedinidae } & Ceryle rudis & Lesser Kingfisher & Pakra machranga & 13.47 & FC & $\mathrm{R}$ & LR & $\mathrm{P}, \mathrm{R}, \mathrm{H}, \mathrm{Dt}$ & $\mathrm{P}$ \\
\hline & Alcedo atthis & Common Kingfisher & Choto machrangha & 31.98 & $\mathrm{C}$ & $\mathrm{R}$ & LR & $\mathrm{P}, \mathrm{R}, \mathrm{Dt}$ & $\mathrm{P}$ \\
\hline & A. meninting & Blue Ear Kingfisher & Machranga & 10.90 & FC & $\mathrm{R}$ & LR & $\mathrm{P}, \mathrm{R}$ & $\mathrm{P}$ \\
\hline Family -Meropidae & Merops orientalis & Green Bee Eater & Shuichora & 19.23 & $\mathrm{C}$ & $\mathrm{R}$ & DD & $\mathrm{Cl}$, Of & I \\
\hline & Micropternus brachyurus & Eastern Rufous & Lalchey kaththokra & 27.31 & $\mathrm{C}$ & $\mathrm{R}$ & LR & $\mathrm{Tt}$ & I \\
\hline Order - Piciformes & & & & & & & & & \\
\hline Family - Picidae & Dinopium benghalense & $\begin{array}{l}\text { Golden Back } \\
\text { Woodpecker }\end{array}$ & Sonali pit kaththokra & 32.06 & $\mathrm{C}$ & $\mathrm{R}$ & LR & $\mathrm{Tt}$ & I \\
\hline & Dendrocopos macei & $\begin{array}{l}\text { Fulvous Breasted } \\
\text { Pied Woodpecker }\end{array}$ & Batabi kathkutali & 35.25 & $\mathrm{C}$ & $\mathrm{R}$ & LR & $\mathrm{Tt}$ & I \\
\hline Passerine bird & & & & & & & & & \\
\hline Order - Passeriformes & & & & & & & & & \\
\hline Family - Hirundinidae & Lanius schach & Black Headed Shrike & Kalashir Koshai & 14.11 & FC & $\mathrm{R}$ & LR & $\mathrm{Cl}$, Of, Bh & I \\
\hline & L. cristatus & Brown Shrike & Dhusher koshai & 12.82 & FC & M & - & $\mathrm{Cl}, \mathrm{Of}, \mathrm{Bh}$ & I \\
\hline Family - Oriolidae & Oriolus oriolus & Golden Oriole & Sonali halud pakhi & 24.36 & $\mathrm{C}$ & M & LR & $\mathrm{Tt}, \mathrm{Bh}$ & I \\
\hline & O. xanthornus & Black Headed Oriole & Holdey pakhi & 40.39 & $\mathrm{C}$ & $\mathrm{R}$ & LR & $\mathrm{Tt}, \mathrm{Bh}$ & I \\
\hline Family - Dicruridae & Dicrurus macrocercus & Black Drongo & Fingey & 89.11 & VC & $\mathrm{R}$ & LR & $\mathrm{Cl}, \mathrm{Of}, \mathrm{Bh}, \mathrm{Tt}$ & I \\
\hline & D. leucophaeus & Ashy Drongo & Kalche fingey & 5.25 & $\mathrm{~F}$ & $\mathrm{R}$ & LR & $\mathrm{Tt}, \mathrm{Bh}$ & I \\
\hline Family - Sturnidae & Sturnus contra & Pied Starling & Gobrey shslik & 285.9 & VC & $\mathrm{R}$ & LR & $\mathrm{Cl}, \mathrm{Of}$ & I \\
\hline & Acrodotheres tristis & Common myna & Bhat shalik & 210.9 & VC & $\mathrm{R}$ & LR & Cl, Of, Hh & M \\
\hline & A. fuscus & Jungle Myna & Jhuti shalik & 114.8 & VC & $\mathrm{R}$ & LR & $\mathrm{Cl}$, Of & I \\
\hline Family - Corvidae & Dendrocitta vagabunda & Rufous Treepie & Harichacha & 45.52 & VC & $\mathrm{R}$ & LR & $\mathrm{Tt}, \mathrm{Hh}$ & M \\
\hline & Corvus splendens & House Crow & Pati kak & 17.52 & VC & $\mathrm{R}$ & LR & $\mathrm{Bh}, \mathrm{Tt}$ & $\mathrm{S}$ \\
\hline & C. macrorhynchos & Jungle Crow & Dar kak & 33.98 & $\mathrm{C}$ & $\mathrm{R}$ & LR & $\mathrm{Bh}, \mathrm{Of}, \mathrm{Tt}$ & S \\
\hline Family - Pycnonotidae & Turdus cafer & Red vented Bulbul & Bulbuli & 275 & VC & $\mathrm{R}$ & LR & $\mathrm{Bh}, \mathrm{Of}$ & I \\
\hline Family - Muscicapidae & Orthotomus sutorius & Tailor Bird & Tuntunis & 39.11 & $\mathrm{VC}$ & $\mathrm{R}$ & LR & $\mathrm{Bh}$ & I \\
\hline & Prinia inornata & Plain Prinia & Bonu tuni & 19.23 & $\mathrm{C}$ & $\mathrm{R}$ & LR & $\mathrm{Bh}$ & I \\
\hline & Copsychus saularis & Magpie & Magpie robin & 45.52 & VC & $\mathrm{R}$ & LR & $\mathrm{Cl}, \mathrm{Bh}, \mathrm{Hh}$ & I \\
\hline Family - Paridae & Parus major & Grey Tit & Tit poukh & 30.77 & VC & $\mathrm{R}$ & LR & $\mathrm{Bh}, \mathrm{Tt}$ & I \\
\hline Family - Nectarinidae & Nectarinia zeylonica & $\begin{array}{l}\text { Purple Rumped } \\
\text { Sunbird }\end{array}$ & Moutushi & 13.47 & FC & $\mathrm{R}$ & LR & $\mathrm{Tt}, \mathrm{Hh}$ & $\mathrm{N}$ \\
\hline Family - Motacillidae & Anthus campestris & Tawny Pipit & Mat chorai & 50.00 & FC & $\mathrm{M}$ & LR & $\mathrm{Cl}$ & I \\
\hline Family - Passeridae & Passer domesticus & House Sparrow & Churoi & 480.13 & VC & $\mathrm{R}$ & LR & Hh, Of & $\mathrm{G}$ \\
\hline Family - Ploceidae & Ploceus philippinus & Baya Weaver & Babui & 69.88 & $\mathrm{C}$ & $\mathrm{R}$ & LR & $\mathrm{Cl}, \mathrm{Tt}$ & G \\
\hline
\end{tabular}

Abbreviation: ${ }^{1} \mathrm{PD}=$ Population Density, ${ }^{2} \mathrm{RA} / \mathrm{RS}=$ Relative Abundance $/$ Resident Status, ${ }^{3} \mathrm{IUCN}=$ International Union for Conservation of Nature, NS = National Status, ${ }^{4} \mathrm{HU}=$ Habitat Utilization, ${ }^{5} \mathrm{FH}=$ Feeding Habit, $\mathrm{VC}=$ Very Common, $\mathrm{C}=$ Common, $\mathrm{FC}=$ Fairly Common, $\mathrm{F}=\mathrm{Few}, \mathrm{R}=\mathrm{Resident}, \mathrm{M}=$ Migratory, CR = Critically Endangered, EN= Endangered, LR = Lower Risk, DD = Data Deficient, Bh = Bush, Of = Open field, $\mathrm{Hh}=\mathrm{Human}$ habitation, $\mathrm{Cl}$ $=$ Cultivated land, $\mathrm{Tt}=$ Tall tree, $\mathrm{H}=$ Hole, $\mathrm{R}=$ River, $\mathrm{P}=$ Pond, $\mathrm{C}=$ Canal, $\mathrm{Dt}=$ Ditch, $\mathrm{We}=$ Water edge, $\mathrm{p}=$ Piscivore, $\mathrm{r}=\mathrm{Raptor}, \mathrm{g}=\mathrm{Granivore}, \mathrm{O}=$ omnivore, $\mathrm{S}=$ Scavenger, $\mathrm{I}=$ Insectivore, $\mathrm{F}=$ Frugivore, $\mathrm{N}=$ Nectar feeder. 
Out of 37 species of resident birds, 7 (18.91\%) were included in the threatened categories at the national level. Of the threatened birds, $2(5.4 \%)$ were critically endangered, $3(8.1 \%)$ endangered and $2(5.4 \%)$ vulnerable (Table 1 \& Fig. 4). Besides these, unavailability of nesting trees, fruittrees and increase of human activities in and around the study site has been contributing to decline the diversity of avifauna.

\section{Conservation Issues- Threats and Problems:}

Avifauna of the study area has been reducing rapidly mainly due to illegal exploitation of trees, cutting of tree branches and destroying the natural habitats e.g., bushes, jungles, thickets, etc. Illegal trapping and shooting of birds by the local people also destroy the diversity and population of bird species

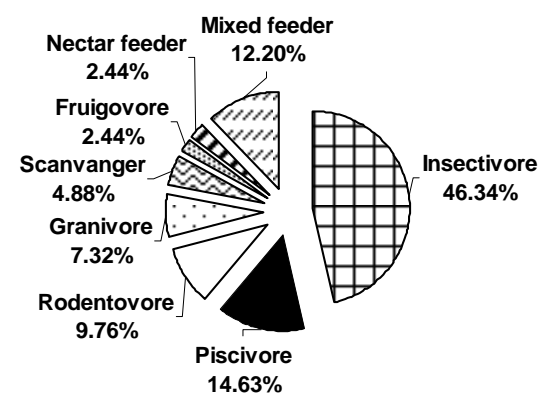

Fig. 3. Feeding habits of birds in BARD, Comilla.

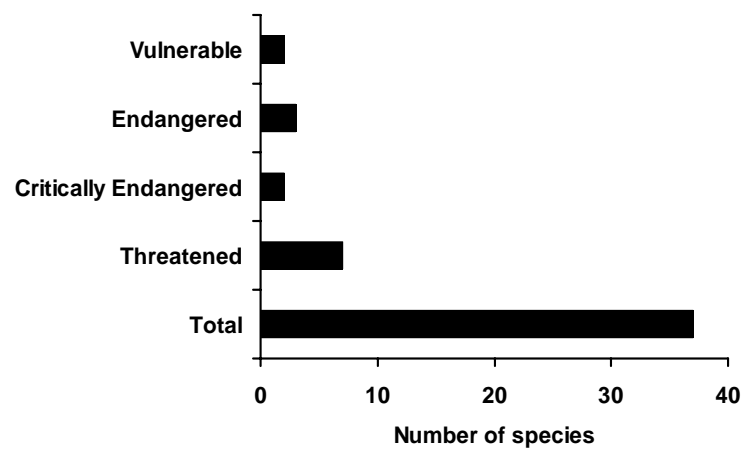

Fig. 4. IUCN threatened categories of recorded birds at BARD.

Village children collect young birds to use as cage bird or play with them for their recreation. Many birds were killed at the study area by poisoning them while people using insecticides in their cultivated land. Another important cause is to kill the pond heron, little egret, common myna, pied starling, jungle myna and some other game birds by using poison bait at the study area.

\section{Recommendations}

Regular patrolling by trained persons should control unwise exploitation of forest resources. Plantation of indigenous fruit-trees is necessary to create natural food sources for fruigivorous birds. Trapping and shooting should be prohibited. Use of highly poisonous insecticides in the agricultural fields adjacent to the study area should not be allowed. A management action plan should be prepared and implemented with the cooperation of National and International organizations for conservation of these bird resources in the study area. Conservation biologist and government should work together with the local communities to create awareness for the conservation of avian diversity in the study area. Establishment of Wildlife Conservation and Management department should be given priority to train people for conservation and monitoring the diversity of avifauna.

\section{References}

Akter, S. 1977. The wildlife fauna of Baldah Garden, Dhaka (with notes on ecology, habitat and present status). M.Sc. thesis (unpublished), Department of Zoology, University of Dhaka, Bangladesh.

Ali, S. \& Ripley, S.D. 1968-1974. The Books of the bird of India and Pakistan. Vols. 1-10. Oxford University Press. Bombay, London, New York.

Ali, S. \& Ripley, S.D. 1983. A Pictorial Guide to the Birds of the Indian Subcontinent. Bombay Nat. Hist. Soc. Oxford University Press, 737 pp.

Annonymus. 2000. Red book of threatened birds, IUCN -World Conservation Union.

Das, S.R. 1972. Birds of Sylhet. M.Sc. thesis (unpublished), Department of Zoology, University of Dhaka, Bangladesh.

Haque, M.N. 1975. The avifauna of Madhupur Forest (With notes on ecology, status, distribution and food). M.Sc. thesis (unpublished), Department of Zoology, University of Dhaka, Bangladesh.

Harvey, W.G. 1990. Birds in Bangladesh, University Press Ltd., Dhaka, Bangladesh. Hossain, M.L. \& Sarker, S.U 1997. Birds of Hatiya Island, Noakhali, Bangladesh. Dhaka Univ. J. Biol. Sci. 6(1): 39-48.

Husain, K.Z., Rahman, M.K., Haque, M.N. \& Sarker, S.U. 1992. Ecology and food habits of roadside birds from Chittagong to Technaf. Bangladesh J. Zool. 20(1): 71- 86.

Husain, K.Z., Sarker, S.U. \& Rahman, M.M. 983. Summer birds of the Sundarbans 'Nilkamal Sanctuary', Bangladesh. Bangladesh J. Zool. 11(1): 48-51.

Husain. K.Z. \& Sarker, S.U. 1979. Notes on a collection of birds from Pabna. J. Asiat. Soc. Bangladesh. 5(1): 15-24

Islam, T. 1970. Birds of Rangpur. M.Sc. thesis (unpublished), Department of Zoology, University of Dhaka, Bangladesh.

Jaman, M. F., Haque, M.S.Z. \& Sarker, S.U. 2004. Ecology, conservation problems and status of avifauna of Noakhali Charbata coastal area. J. NOAMI. 21(1): 1-13.

Khan, M.A.R. 2010. Wildlife of Bangladesh from Amphibia to Mammalia. A checklist. Shahitya Prakash, 87 Purana Palton Line, Dhaka 1000, 128 pp.

Rahman, M.M. 1971. Birds of Faridpur. M.Sc. thesis (unpublished), Department of Zoology, University of Dhaka, Bangladesh.

Sarker, S.U. \& Sarker, N.J. 1983. Endangered wildlife of Bangladesh. Tiger paper. 10(2): 26-28.

Sarker, S.U. 1983. Status and distribution of vultures of Bangladesh. J. Vulture Study. 9 10: 40-41. 